\title{
nature
}

\section{How to shoot down spaceships}

\section{Mr Caspar Weinberger, the US Secretary of Defense, seems to have put paid to international participation in the US space station. Some putative partners may be grateful to him.}

IT is always refreshing when powerful statesmen are willing to make their opinions public. Mr Michael Foot, when a minister in the British government and as leader of the Labour Party opposition in the House of Commons, was a frequent contributor to the newspaper correspondence columns. Mr Caspar Weinberger, the US Secretary of Defense, is similarly unafraid to let what he thinks become generally known. Even those who may believe that his article in the New York Times ten days ago about the prospects for arms control was a tactless public warning to his colleague Mr George Schultz, the US Secretary of State, will have been glad of the information it contains. Almost at the same time, it now appears, Weinberger was writing privately to Shultz to warn him against an over-obtrusive foreign presence on the US space station planned for 1994 (see Nature 326, 628; 1987). In the way that these things happen, Weinberger's letter seems to have enjoyed almost as wide and rapid a circulation as if that, too, had been sent to a newspaper. But, apart possibly from Shultz, the most attentive readers of the letter will be the putative partners in the venture - Canada, the members of the European Space Agency (ESA) and Japan. They may not be as downcast by its tone as may be thought.

There is nothing new or surprising in the US military's declaration of an interest in the project. So much has been made plain from the outset. It would be surprising if it were otherwise; there are a great many ways in which military people could use a space station without compromising the US government's understanding with its potential partners that the enterprise was intended to be essentially civilian. The military, who have forced the pace of observation in many fields of geophysics, oceanography for example, no doubt have a great deal of data-gathering to do in relatively low orbits about the Earth. Moreover, it would be disingenuous to pretend that everything done in such a laboratory should be open to public inspection; indeed, among the potential partners are some who believe there is a commercial fortune to be made from microgravity experiments, and who plan that some of their nationals should carry out experiments whose results will be kept secret even from the other occupants of the rig, and which may never be published. The notion that there might also be military programmes of work seems to have been more or less accepted until late last year, when the Pentagon asked the National Aeronautics and Space Administration (NASA), the lead agency for the project, to match its developing contractual relationships with its partners overseas against the possible interests of the US military.

\section{Unanticipated needs}

Things have not gone right since then. There is no reason to dispute the Pentagon's flat assertion that it has nothing particular in mind, but that it is merely concerned that unanticipated future needs will not be denied by arrangements made now. But the military might have guessed that asking for a formal review last December would have confirmed some of the partners in their indecision about the wisdom of participation. It is an open secret that some of the foreign candidates for partnership plan to participate only because others are going along, and because they may be left behind. Canada is probably in this case, together with several ESA members. Other governments, that of the Netherlands for example, are genuinely alarmed at the political capital their opponents would make of what might be presented as tainted collaboration. And what is to be made of the British government, which has set up its own National Space Centre but has (so far) been unable to find the budget to make the centre a reality? That is hardly an augury of enthusiastic participation. The plain truth is that the more insistently the Pentagon has asked that its unperceived needs should be accommodated, the more zealous some partners have become in demanding that everything should be spelled out in advance. Cynics might be forgiven for thinking that some of the difficulties raised have been meant to dash the prospects for collaboration altogether.

\section{Strong words}

Now, Weinberger's letter probably ensures that that is what will happen. It is the tone that will do the damage. Literally, it asks that the United States should "resist compromise" with its partners on four stated principles - the right to conduct "national security activities" on the US elements of the structure without approval or review; there must be no "multilateral decision-making" on the management, operation and use of the space station; no "one-way flow of US space technology" ( sic); and "equal partnership" must not displace either "the reality or the symbol of US leadership" in the project. Like the quarrelsome partners, Weinberger is simply asking that the fine print should be made plain, and that the minor partners should be told of the degree of influence to which their small contributions will entitle them. The obvious difficulty, for the putative partners, is that the message will make them more and not less intransigent.

In the long run, none of this will matter very much. Even now, there is a chance that what looks like the beginning of a substantial transatlantic row will be papered over. But there is a sense in which the gilt, such as it ever was, has been rubbed off the space station before any metal has been cut. Where Europe (represented by ESA) is concerned, there is anyway a strong case for a reconsideration of what needs to be done, in fields of technology of which space, and man in space in particular, is only one. If cool consideration showed that the first need is to make the Ariane rocket work properly, and better, that would be no great surprise. Beyond that are a string of smaller but still costly projects that need to be carried through. Japan is in much the same case. If Canada feels too neglected, it might join one or the other. Some decades hence, the circumstances may be very different. Meanwhile, the most urgent need is that the tradition of collaboration on the exploration of the Solar System between the United States and the partners in the space station and also the Soviet Union should not be allowed to lapse. If NASA is likely to be preoccupied with the space shuttle and the space station for at least the next six years, might not the minor partners more usefully devote themselves to collaborative exploration? 